\title{
KINETIC STUDIES OF MANGANESE REMOVAL FROM AQUEOUS SOLUTION BY ADSORPTION ON NATURAL ZEOLITE*
}

\author{
Afrodita Zendelska ${ }^{1 *}$, Mirjana Golomeova ${ }^{1}$, Krsto Blažev ${ }^{2}$, Blažo Boev ${ }^{1}$, Boris Krstev ${ }^{1}$, \\ Blagoj Golomeov ${ }^{1}$, Aleksandar Krstev ${ }^{3}$ \\ ${ }^{1}$ Faculty of Natural and Technical Sciences, Goce Delčev University, 2000 Štip, Republic of Macedonia \\ ${ }^{2}$ Faculty of Technology, Goce Delčev University, Probištip, Republic of Macedonia \\ ${ }^{3}$ Faculty of Computer Science, Goce Delčev University, 2000 Štip, Republic of Macedonia \\ *afrodita.zendelska@ugd.edu.mk
}

The kinetics of manganese adsorption onto natural zeolite (clinoptilolite) was studied in terms of initial metal ion concentration and adsorbent mass. In order to select the main rate-determining step in the overall uptake mechanism, a series of experiments was performed under batch conditions from single ion solutions. Data obtained from the kinetic experiments are interpreted in terms of pseudo-second order kinetic model, Weber and Morris model and model proposed by Furusawa and Smith.

The adsorption kinetics is reasonably fast. It means that in the first 20 min approximately $75 \%$ of $\mathrm{Mn}^{2+}$ is adsorbed from solutions. From the kinetic data, it can be concluded that adsorption of manganese ions from solution by natural zeolite is more efficient at higher adsorbent mass and at lower manganese concentration in solution. The amount of $\mathrm{Mn}$ adsorbed on zeolite increases at higher manganese concentration in solution.

From the kinetic models, it can be concluded that intraparticular diffusion is more likely to be the rate determining step, but at higher concentrations of $\mathrm{Mn}$ ions in solution, film diffusion may take a part in a rate determining step.

Key words: manganese ions; adsorption; zeolite; kinetic

\section{ИСПИТУВАЊЕ НА КИНЕТИКАТА НА ОТСТРАНУВАЊЕТО НА МАНГАН ОД ВОДНИ РАСТВОРИ СО АТСОРПЦИЈА НА ПРИРОДЕН ЗЕОЛИТ}

Кинетиката на атсорпцијата на манган со природен зеолит (клиноптилолит) е испитувана во зависност од почетната концентрација на јони на манган во растворот и масата на атсорбентот. Со цел да се определи најбавниот чекор на реакцијата, преку кој би се определила вкупната брзина на реакцијата, изведени се серија експерименти во еднокомпонентни раствори. Добиените податоци се интерпретирани со: псевдо кинетичкиот модел од втор ред, моделот на Weber и Morris и моделот предложен од Furusawa и Smith.

Резултатите покажуваат дека атсорпцијата се одвива релативно брзо. Тоа значи дека во првите $20 \mathrm{~min}$ околу $75 \%$ од јоните на манган во растворот се атсорбирани на клиноптилолитот. Од податоците од испитувањето на кинетиката може да се заклучи дека атсорпцијата на мангановите јони е поефикасна при поголема маса на атсорбент и при пониска концентрација на манган во растворот. Количината на атсорбиран манган врз зеолитот се зголемува со порастот на концентрацијата на јоните на манган во растворот.

Од моделирањето на кинетиката може да се заклучи дека поверојатно е чекорот со кој се определува брзината на атсорпцијата да биде дифузијата во внатрешноста на честичката, но при повисоки концентрации на јони на манган во растворот за определување на чекорот може да се земе во предвид и филм-дифузијата.

Клучни зборови: јони на манган; атсорпција; зеолит; кинетика

\footnotetext{
- Dedicated to Academician Gligor Jovanovski on the occasion of his $70^{\text {th }}$ birthday.
} 


\section{INTRODUCTION}

Zeolite is a natural porous mineral in which the partial substitution of $\mathrm{Si}^{4+}$ by $\mathrm{Al}^{3+}$ results in an excess of negative charge. This is compensated by alkali and alkaline earth cations $\left(\mathrm{Na}^{+}, \mathrm{K}^{+}, \mathrm{Ca}^{2+}\right.$ or $\left.\mathrm{Mg}^{2+}\right)$. Zeolites have been used as adsorbents, molecular sieves, membranes, ion-exchangers and catalysts, mainly because zeolite exchangeable ions are relatively innocuous. Thus, zeolites are particularly suitable for removing undesirable heavy metal ions (e.g. lead, nickel, zinc, manganese, cadmium, copper, chromium and/or cobalt), radionuclides as well as ammoniacal nitrogen (ammonia and ammonium) from municipal wastewaters, metal plating facilities, electroplating, mining operations, fertilizers, battery manufacture, dyestuffs, chemical pharmaceutical, electronic device manufactures and many others [1]. Most of the heavy metals are highly toxic and are non-biodegradable, therefore they must be removed from the polluted streams in order to meet increasingly stringent environmental quality standards. The removal of heavy metal cations using natural zeolites was studied by many authors [1-10].

Most of published paper on adsorption of metallic ions are aimed at assessing the adsorption capacity $[1,2,5,6,8,9,10]$, and only a few attempts have been made to elucidate the mechanism of binding [11]. The adsorption mechanism depends strongly on the nature of the adsorbent. The aim of this work was to investigate the adsorption of manganese ions onto a natural zeolite (clinoptilolite) whereby the main parameters were the adsorption kinetics and the rate-determining step. The obtained information will be a basis for further research for acid mine drainage treatment with zeolite.

\section{EXPERIMENTAL}

\subsection{Adsorbent}

The natural zeolite (clinoptilolite) was used in the recent study as an adsorbent for adsorption of manganese ions. The particle size range of the natural zeolite used in this study was 0.8 to $2.5 \mathrm{~mm}$.

The chemical composition of natural zeolite is presented in Table 1 .

X-ray diffractometer 6100 from Shimadzu was used to investigate the mineralogical structure of natural zeolite samples. This technique is based on observing the scattering intensity of an X-ray beam hitting a sample as a function of incident and scattered angle, polarization and wavelength or energy. The diffraction data obtained are compared to the database maintained by the International Centre for Diffraction Data, in order to identify the material in the solid samples. The results of XRD (Fig. 1) showed that the natural zeolite contained clinoptilolite in the majority.

The surface morphology of natural zeolite was studied using a scanning electron microscope VEGA3 LMU. This particular microscope is also fitted with an Inca 250 EDS system. EDS, stands for Energy Dispersive Spectroscopy, it is an analytical technique used for the elemental analysis of a sample based on the emission of characteristic Xrays by the sample when subjected to a high energy beam of charged particles such as electrons or protons.

\section{Table 1}

Chemical composition of zeolite samples

\begin{tabular}{|c|c|c|c|}
\hline \multicolumn{4}{|c|}{ Typical chemical composition in $\% \mathrm{wt}$} \\
\hline $\mathrm{SiO}_{2}$ & 69.68 & $\mathrm{CaO}$ & 2.01 \\
\hline $\mathrm{Al}_{2} \mathrm{O}_{3}$ & 11.40 & $\mathrm{Na}_{2} \mathrm{O}$ & 0.62 \\
\hline $\mathrm{TiO}_{2}$ & 0.15 & $\mathrm{~K}_{2} \mathrm{O}$ & 2.90 \\
\hline $\mathrm{Fe}_{2} \mathrm{O}_{3}$ & 0.93 & $\mathrm{H}_{2} \mathrm{O}$ & 13.24 \\
\hline $\mathrm{MgO}$ & 0.87 & $\mathrm{P}_{2} \mathrm{O}_{5}$ & 0.02 \\
\hline $\mathrm{MnO}$ & 0.08 & ratio $\mathrm{Si} / \mathrm{Al}$ & $4.0-5.2$ \\
\hline \multirow{4}{*}{\multicolumn{2}{|c|}{$\begin{array}{l}\text { Cation exchange } \\
\text { per cation }\end{array}$}} & $\mathrm{K}^{+}$ & $41 \mathrm{meq} / 100 \mathrm{~g}$ \\
\hline & & $\mathrm{Na}^{+} \quad 16$. & $16.10 \mathrm{meq} / 100 \mathrm{~g}$ \\
\hline & & $\mathrm{Ca}^{2+} 67$. & $67.14 \mathrm{meq} / 100 \mathrm{~g}$ \\
\hline & & $\mathrm{Mg}^{2+} \quad 3$. & $3.88 \mathrm{meq} / 100 \mathrm{~g}$ \\
\hline \multicolumn{2}{|c|}{$\begin{array}{c}\text { Total cation } \\
\text { exchange capacity }\end{array}$} & \multicolumn{2}{|c|}{$1.8-2.2 \mathrm{meq} / \mathrm{g}$} \\
\hline
\end{tabular}

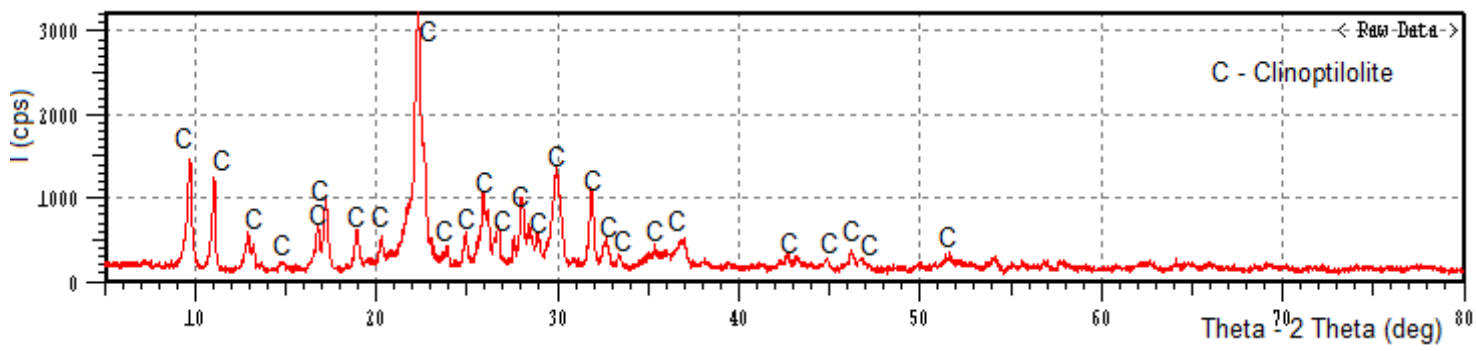

Fig. 1. X-ray diffractionof natural zeolite 
Micrographs of natural zeolite samples obtained from SEM analysis are given in Figure 2. The micrographs clearly show a number of macropores in the zeolite structure. The micrographs also show well defined crystals of clinoptilolite.
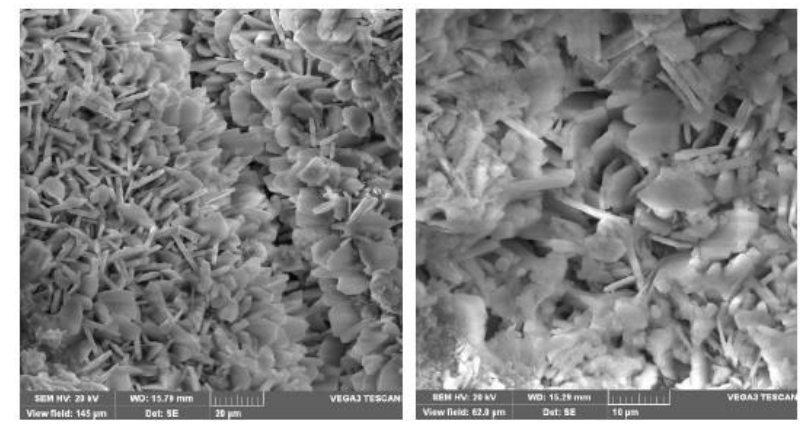

Fig. 2. Micrographs of natural zeolite samples obtained from SEM analysis

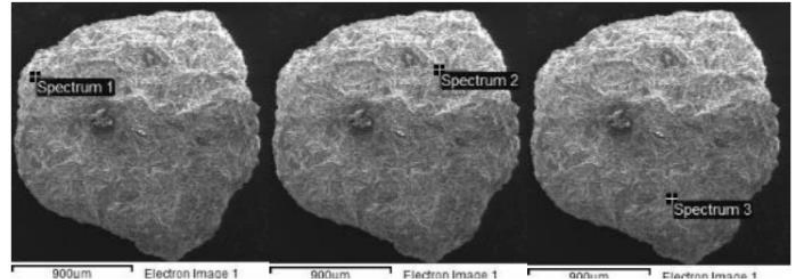

Fig. 3. EDS analysis showing the scanning method fornatural zeolite

An electron beam was directed to different parts of the samples in order to get a more accurate analysis (Fig.3) and the elemental composition of natural zeolite (clinoptilolite) are presented in Table 2 .

The results of EDS analysis showed that the predominant exchangeable cations in natural zeolite (clinoptilolite) structure were $\mathrm{K}^{+}$and $\mathrm{Ca}^{2+}$.

Table 2

EDS analysis showing the elemental composition for natural zeolite

\begin{tabular}{llllllllll}
\hline \hline & $\mathrm{O}$ & $\mathrm{Na}$ & $\mathrm{Mg}$ & $\mathrm{Al}$ & $\mathrm{Si}$ & $\mathrm{K}$ & $\mathrm{Ca}$ & $\mathrm{Fe}$ & Total \\
\hline Spectrum 1 & 58.46 & 0.27 & 0.72 & 5.28 & 29.55 & 2.73 & 1.9 & 1.1 & 100 \\
Spectrum 2 & 55.4 & 0.15 & 0.66 & 5.52 & 31.36 & 2.96 & 2.42 & 1.53 & 100 \\
Spectrum 3 & 58.83 & 0.3 & 0.77 & 5.03 & 29.47 & 2.44 & 1.66 & 1.5 & 100 \\
Average & 57.56 & 0.24 & 0.72 & 5.28 & 30.13 & 2.71 & 1.99 & 1.38 & 100 \\
\hline Std. deviation & 1.882 & 0.079 & 0.055 & 0.245 & 1.068 & 0.26 & 0.388 & 0.24 & \\
\hline \hline
\end{tabular}

\subsection{Adsorbate}

The heavy metal, Mn, was used as adsorbate in the recent investigations. Synthetic single component solutions of $\mathrm{Mn}^{2+}$ were prepared by dissolving a weighed mass of the analytical grade salt $\mathrm{MnSO}_{4} \cdot \mathrm{H}_{2} \mathrm{O}$ in $1000 \mathrm{ml}$ distilled water. Initial $\mathrm{pH}$ of prepared solutions was adjusted by adding $2 \%$ sulfuric acid and controlled by 210 Microprocessor $\mathrm{pH}$ Meter.

\subsection{Experimental procedure}

Adsorption of manganese ions on zeolite was performed with synthetic single ion solutions of $\mathrm{Mn}^{2+}$ ions with different initial concentration (5, $25,50$ and $200 \mathrm{mg} / \mathrm{l})$ and adsorbent mass $(2,5$ and $10 \mathrm{~g})$. The experiments were performed in a batch mode in a series of beakers equipped with magnetic stirrers at $400 \mathrm{rpm}$. The agitation time was varied up to 120 minutes. At the end of the predetermined time, the suspension was filtered and the filtrate was analyzed. The final $\mathrm{pH}$ value was also measured. The initial and remaining concentrations of metal ions were determined by ISP Emission Spectrometer. All experiments were performed at room temperature of $20 \pm 1^{\circ} \mathrm{C}$.

The adsorption capacity was calculated by using the following expression [3]:

$$
q_{\mathrm{e}}=\frac{V\left(C_{\mathrm{b}}-C_{\mathrm{e}}\right)}{m}(\mathrm{mg} / \mathrm{g})
$$

where: $q_{\mathrm{e}}$ is the mass of adsorbed metal ions per unit mass of adsorbent $(\mathrm{mg} / \mathrm{g}), C_{0}$ and $C_{\theta}$ are the initial and final metal ion concentrations $(\mathrm{mg} / \mathrm{l})$, respectively, $V$ is the volume of the aqueous phase (l) and $m$ is the mass of adsorbent used (g). culated as:

Degree of adsorption, in percentage, is cal-

$$
A D \%=\left(1-\frac{C_{Q}}{C_{0}}\right) \cdot 100
$$

\subsection{Kinetic studies}

Kinetic studies are important because they supply information about the process dynamics, that is, the adsorption rate, residence time and mass 
transfer parameters such as external mass transfer coefficients and intraparticle diffusivity. These parameters are essential in the design and operation of any adsorption column in waste water treatment plants. Therefore, kinetic studies help to evaluate the suitability of any material as a potential adsorbent in removing pollutants from solution [12].

A number of kinetic models were identified and used to describe the uptake process/mechanism. The models used in this investigation are the pseudo-second order kinetic model for chemisorption, Weber and Morris model about intraparticle diffusion and the film diffusion model as proposed by Furusawa and Smith.

\subsubsection{Pseudo-second order kinetic model}

The pseudo-second order kinetic model was used to investigate whether chemical reaction at the adsorption sites of zeolite was rate controlling. The experimental data that fit to this model indicate that chemical reaction is involved in the removal of heavy metals from solution, that is chemisorption [13, 14].

The pseudo second order kinetic model is given by Eqs. 3 and 4:

$$
\begin{aligned}
& \frac{d q}{d t}=k_{2}\left(q_{e}-q\right)^{2} \\
& \frac{t}{q}=\frac{1}{k_{2} \cdot q_{e}^{2}}+\frac{t}{q_{e}}
\end{aligned}
$$

where $q$ and $q_{e}$ are the amount of metal adsorbed per unit weight of adsorbent $(\mathrm{mg} / \mathrm{g})$ at time $t$, and at equilibrium, respectively, $k_{2}$ is adsorption rate constant.

\subsubsection{Film transfer diffusion control (external mass transfer)}

Film transfer control was determined using a method proposed by Furusawa and Smith, 1973 $[11,15,16,17]$. The change in metal concentration with respect to time is related to the external mass transfer coefficient, $k_{s}(\mathrm{~cm} / \mathrm{s})$, by the Eq. 5 :

$$
\frac{d C_{\mathrm{e}}}{d t}=-k_{s} S_{s}\left(C_{\mathrm{e}}-C_{g}\right)
$$

where $C_{\mathrm{e}}$ is the liquid phase solid concentration at a time $t, C_{s}$ is the liquid phase solute concentration at the particle surface, and $S_{s}(1 / \mathrm{cm})$ is the specific surface area for mass transfer.

$$
S_{s}=\frac{6 m_{s}}{d_{p} \rho_{t}\left(1-s_{p}\right)}
$$

where $m_{s}\left(\mathrm{~g} / \mathrm{cm}^{3}\right)$ is the sorbent mass concentration in the solution, $d p$ is the diameter of the zeolite particles $(\mathrm{cm}), \rho_{t}$ is the density of solid phase $\left(\mathrm{g} / \mathrm{cm}^{3}\right)$ and $\varepsilon_{p}$ is the porosity of the zeolite particles.

\subsubsection{Intraparticle diffusion model}

Weber and Morris, 1962 [18] theorized that the rate of intraparticle diffusion varies proportionally with the square root of time and is expressed as:

$$
q_{t}=k_{i} \cdot t^{1 / 2}+c
$$

where $q_{t}(\mathrm{mg} / \mathrm{g})$ is adsorbate uptake at time $t, k_{i}$ is the rate constant of intraparticle transport $\left(\mathrm{mg} / \mathrm{g}_{-} \mathrm{t}^{1 / 2}\right)$.

The values of interception, $c$, are related to the boundary layer thickness, i.e. the larger the value of the intercept, the greater the boundary layer effect $[13,18]$.

\section{RESULTS AND DISCUSSION}

\subsection{Effect of initial solution concentration}

The results of the kinetic experiments to measure the adsorption of cations from aqueous solutions onto the natural zeolite as a function of initial concentration of $\mathrm{Mn}$ in solution and time are shown in Figure 4. Single component solutions of $400 \mathrm{ml}$ were mixed with $5 \mathrm{~g}$ natural zeolite and agitated for 120 minutes at the temperature $20 \pm 1$ ${ }^{\circ} \mathrm{C}$ and $\mathrm{pH}$ value 3.5. The concentration of the single component solution was 5, 25, 50 and 200 $\mathrm{mg} / \mathrm{l}$ of $\mathrm{Mn}^{2+}$. These concentrations were used because content of $\mathrm{Mn}$ in some polluted mine waters in Macedonia ranges from 3 up to $300 \mathrm{mg} / \mathrm{l}$.

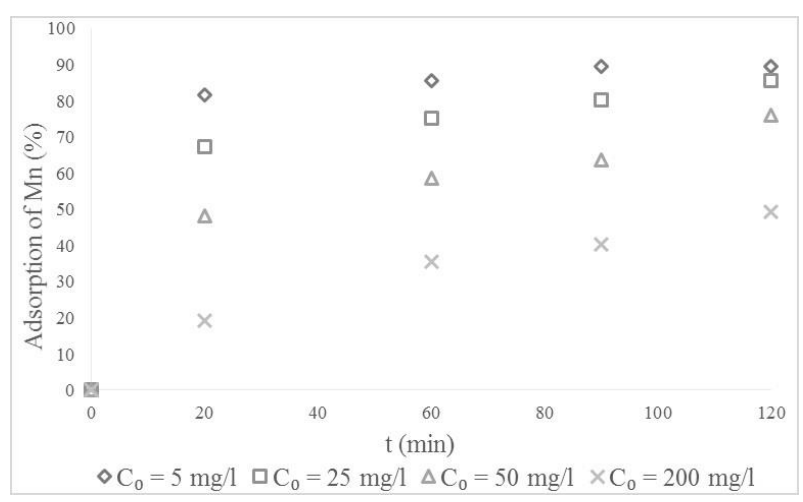

Fig. 4. Effect of initial $\mathrm{Mn}^{2+}$ concentration on the adsorption of zeolite

An increase in concentration generally results in an increase in the amount of manganese adsorbed and the rate of adsorption. This may be a 
result of an increase in collisions between the reactants, leading to the observed increase in reaction rate and capacity according to the Collision Theory [12]. The adsorption capacity will increase with an increase in initial concentration until the system reaches a saturation point, at which point further increase of the adsorbate (Mn) concentration will not result in any significant change in the amount adsorbed, $q_{e}$. Table 3 presents the results of this investigation.

\section{Table 3}

Effect of initial solution concentration on the adsorption capacity of natural zeolite

\begin{tabular}{cccc}
\hline $\begin{array}{c}\text { Heavy } \\
\text { metal }\end{array}$ & $\begin{array}{c}\text { Initial } \\
\text { concentration } \\
C_{o}(\mathrm{mg} / \mathrm{l})\end{array}$ & $\begin{array}{c}\text { Amount } \\
\text { adsorbed } \\
q_{e}(\mathrm{mg} / \mathrm{g})\end{array}$ & $\begin{array}{c}\text { Percentage } \\
\text { adsorbed } \\
(\%)\end{array}$ \\
\hline \multirow{3}{*}{$\mathrm{Mn}$} & 5 & 0.358 & 89.60 \\
& 25 & 1.713 & 85.64 \\
& 50 & 3.039 & 75.98 \\
& 200 & 6.960 & 43.45 \\
\hline \hline
\end{tabular}

The above results indicate that the amount of $\mathrm{Mn}$ adsorbed by natural zeolite at equilibrium is dependent on the initial Mn concentration. The increase in the amount of manganese adsorbed as initial concentration is a consequence of an increase in the concentration driving force. The concentration driving force is important because it is responsible for overcoming the mass transfer resistance associated with the adsorption of metals from solution by the zeolite [19]. Therefore, as initial concentration increases, the driving force also increases resulting in an increase in manganese uptake by the zeolite.

Table 3 also reveals that an increase in initial concentration not only results in an increase in the amount adsorbed $\left(q_{\mathrm{e}}\right)$ but a decrease in the efficiency of natural zeolite for the removal of $\mathrm{Mn}$ from solution. Motsi [11] also found a similar trend, that is a decrease in efficiency, in their work on the adsorption of $\mathrm{Cu}, \mathrm{Mn}, \mathrm{Zn}$ and $\mathrm{Fe}$ from solution by clinoptilolite.

\subsection{Effect of adsorbent mass}

A series of kinetic experiments at different adsorbent masses, that is 2,5 and $10 \mathrm{~g}$, were performed using fixed initial metal concentrations for the Mn cation $(200 \mathrm{mg} / \mathrm{l})$. The other conditions were $400 \mathrm{ml}$ solution agitated for 120 minutes at the temperature $20 \pm 1{ }^{\circ} \mathrm{C}$ and $\mathrm{pH}$ value 3.5 .

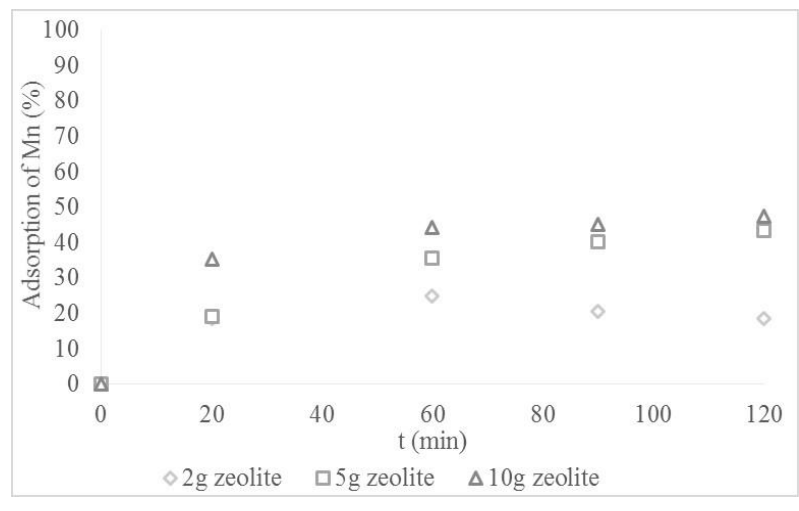

Fig. 5. Effect of adsorbent mass on the adsorption of zeolite

The plots of the amount of metal adsorbed versus time are shown in Figure 5. According to the percentage of Mn adsorbed from solution, we can see that an increase in adsorbent mass resulted in an increase in the adsorption of the Mn (Table 4). This is because as adsorbent mass increases more adsorption sites are available per unit mass of adsorbent added.

Table 4

Effect of adsorbent mass on the efficiency of natural zeolite for the removal of Mn from solution

\begin{tabular}{ccc}
\hline \hline $\begin{array}{c}\text { Heavy } \\
\text { metal }\end{array}$ & $\begin{array}{c}\text { Adsorbent mass } \\
(\mathrm{g})\end{array}$ & $\begin{array}{c}\text { Percentage } \\
\text { adsorbed }(\%)\end{array}$ \\
\hline & 2 & 18.43 \\
$\mathrm{Mn}$ & 5 & 43.45 \\
& 10 & 47.43 \\
\hline \hline
\end{tabular}

\subsection{Kinetic modeling}

Kinetic modelling was carried out to investigate the rate determining step in the removal of $\mathrm{Mn}$ ions from solution by using natural zeolite.

\subsubsection{Pseudo-second order kinetic model}

To test whether the rate of removal of heavy metals from solution by natural zeolite is controlled by chemical reactions (i.e. chemisorption) a number of conditions must be met. These conditions are $[11,20]$ :

- The rate constant should be constant for all values of initial concentration of counter-ions,

- The rate constant should not change with adsorbent particle size,

- The rate constant is sometimes independent of the degree of agitation (stirring rate).

If any of these conditions are not fulfilled, chemical reaction kinetics is not rate determining 
step even if rate data is successfully fitted to the pseudo-second order kinetic model.

One of the above conditions was tested, that is, whether the rate constant remains constant with a change in initial concentration on $\mathrm{Mn}^{2+}$ ion in solution. The results obtained for the adsorption of $\mathrm{Mn}^{2+}$ onto natural zeolite were fitted to Eq. 4. This was achieved by plotting $t / q$ versus $t$, as shown in Figure 6.

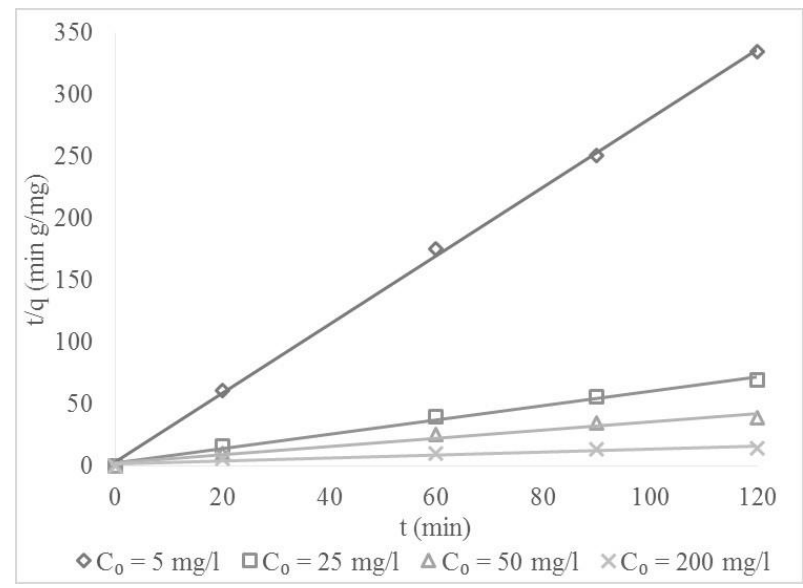

Fig. 6. Effect of initial $\mathrm{Mn}^{2+}$ concentration in solution on the reaction rate constant

Table 5

Variation of rate constant with different initial concentration

\begin{tabular}{ccccc}
\hline \hline$C_{o}(\mathrm{mg} / \mathrm{l})$ & 5 & 25 & 50 & 200 \\
\hline$k_{2}$ & 2.0138 & 0.1193 & 0.0405 & 0.0064 \\
$q_{e}$ & 0.3606 & 1.7268 & 2.9904 & 8.3333 \\
$R^{2}$ & 0.9993 & 0.9932 & 0.9697 & 0.9169 \\
\hline \hline
\end{tabular}

The experimental data (Fig. 6 and Table 5) obtained for the effect of initial concentration on $\mathrm{Mn}^{2+}$ ion in solution according $R^{2}$ gave a good fit to the pseudo-second order kinetic model only when Mn concentration is low, but with increasing concentration of $\mathrm{Mn}$ in solution, experimental data did not give good fit. Also, Table 5, shows that the rate constant, $k_{2}$, for the removal of cations from solution was not constant for different initial concentration on $\mathrm{Mn}^{2+}$ ion in solution. This indicates that chemisorption does not rate determining step in the removal of $\mathrm{Mn}$ from solution by natural zeolite.

\subsubsection{Film transfer diffusion control (external mass transfer)}

The results of the experiments were fitted to the model proposed by Furusawa and Smith and presented on Figures7 and 8 and Table 6. Plotting $\operatorname{In}\left[\left(C_{e} / C_{o}\right)-\left(1 /\left(1+m_{s} K\right)\right)\right]$ vs. time, should give a straight line. The gradient of the straight line is $-\left[\left(1+m_{s} K\right) /\left(m_{s} K\right)\right] k_{s} S_{s} . K$ is Langmuir adsorption isotherm constant $(1 / \mathrm{g})$. The value of $K$ used in equation is taken from our previous studies [23]. The external mass transfer coefficient between the bulk liquid and outer surface of the zeolite particle, $k_{s}$ can then be evaluated.

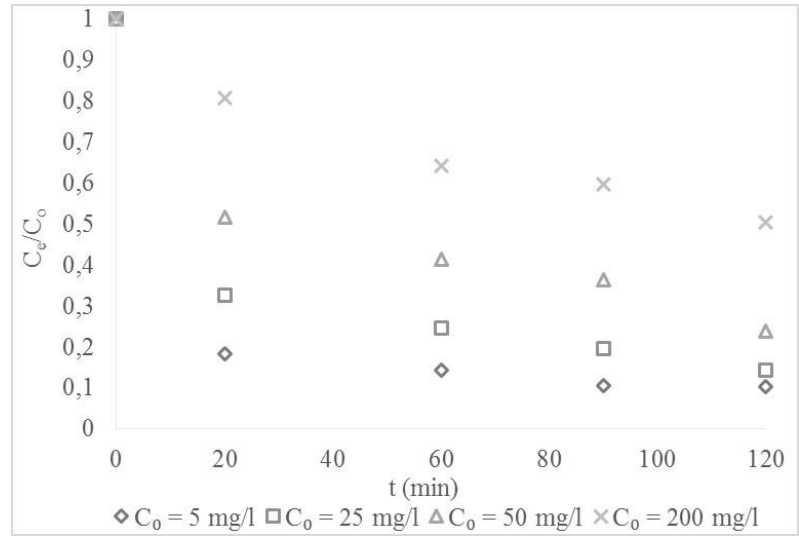

Fig. 7. External mass transfer diffusion model according $C_{e} / C_{o}$ vs. time

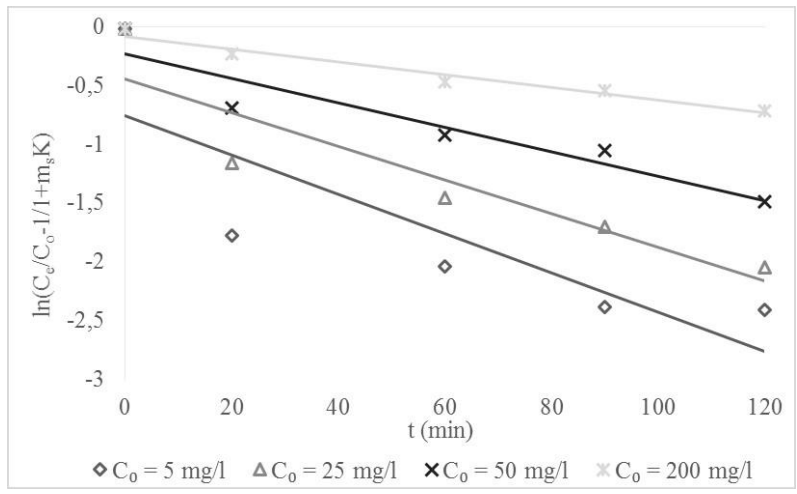

Fig. 8. Fitting externalmasstransfer diffusion model according $\ln \left[\left(C_{e} / C_{o}\right)-\left(1 /\left(1+m_{s} K\right)\right)\right]$ vs. time

From the external mass transfer coefficient, $k_{s}$, it can be concluded that boundary layer surrounding the particle is reduced and similar at all initial Mn concentration and intraparticle diffusion is more likely to be the rate determining step.

Table 6

Calculated film mass transfer coefficients

\begin{tabular}{ccccc}
\hline \hline$C_{o}(\mathrm{mg} / \mathrm{l})$ & 5 & 25 & 50 & 200 \\
\hline$k_{s}(\mathrm{~cm} / \mathrm{s})$ & 0.00067 & 0.00057 & 0.00042 & 0.00022 \\
$R^{2}$ & 0.6861 & 0.8304 & 0.8931 & 0.9637 \\
\hline \hline
\end{tabular}


Correlation coefficient $R^{2}$ is different at all initial Mn concentration and by increasing the concentration of $\mathrm{Mn}$ ions in solution, also increasing $R^{2}$. It means that at the highest concentrations of Mn ions in solution, film diffusion may take part in a rate determining step, but at lower concentration $R^{2}$ is from 0.68 to 0.83 and that indicates allow applicability of this model. This is consistent with the conclusion that in a well-agitated batch system, the boundary layer surrounding the particle is much reduced, reducing the external mass transfer coefficient $k_{s}$, hence, intraparticular diffusion is more likely to be the rate determining step [16, 24].

\subsubsection{Intraparticle diffusion model}

According to Weber and Morris, if the rate determining step is intraparticle diffusion, a plot of solute adsorbed against the square root of the contact time should yield a straight line passing through the origin. Also, the rate constant for intraparticle diffusion is obtained from the slope of the curve.

\section{Table 7}

\section{Calculated the rate constant of intraparticle transport}

\begin{tabular}{ccccc}
\hline \hline$C_{o}(\mathrm{mg} / \mathrm{l})$ & 5 & 25 & 50 & 200 \\
\hline$k_{\mathrm{i}}$ & 0.0311 & 0.1484 & 0.2587 & 0.7122 \\
$R^{2}$ & 0.7689 & 0.8543 & 0.9333 & 0.996 \\
\hline \hline
\end{tabular}

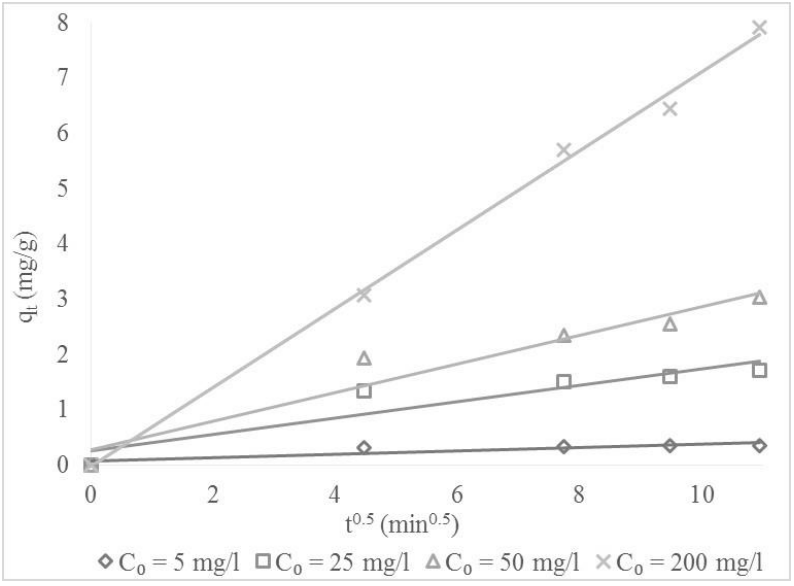

Fig. 9. Intraparticle diffusion control

According to this theory, $C$, the intercept gives an idea about the thickness of boundary layer, i.e. the larger the intercept, the greater the boundary layer effect. If intraparticle diffusion occurs, then $q_{t}$ versus $t_{0.5}$ will be linear and if the plot passes through the origin, then the rate determining step is only due to the intraparticle diffusion. Oth- erwise, some other mechanism along with intraparticle diffusion is also involved [21,22].

In this case the intercept gives different values, but quite close to zero and it means that boundary layer effect is small. As can be seen from Figure 9, the graphic is linear, but as can be seen from $R^{2}$ (Table 7) the plot does not pass through the origin, and can be concluded that the intraparticle diffusion was not the only rate determining mechanism in the adsorption process. Taffarel et al. 2009 [1] in their study have obtained that the intraparticle diffusion model presents a non-linear distribution and $R^{2}$ is from 0.67 to 0.76 , indicating a very low applicability of the model.

\section{CONCLUSION}

The adsorption of Mn ions from diluted solution onto natural zeolite occurs efficiently.

The adsorption kinetics is reasonably fast. It means that in the first 20 min approximately $75 \%$ of $\mathrm{Mn}^{2+}$ is adsorbed from single ion solutions.

From the kinetic data can be concluded that adsorption of manganese ions from solution by natural zeolite is more efficient at higher adsorbent mass and at lower manganese concentration in solution, but the amount of Mn adsorbed on zeolite, increases at higher manganese concentration in solution.

The experimental data obtained for the effect of initial concentration on $\mathrm{Mn}^{2+}$ ions in solution according $R^{2}$ gave a good fit to the pseudo-second order kinetic model only when Mn concentration is low, but with increasing concentration of $\mathrm{Mn}$ in solution, experimental data did not give good fit. Also, the rate constant, $k_{2}$, for the removal of cations from solution, was not constant for different initial concentration on $\mathrm{Mn}^{2+}$ ion in solution. This indicates that chemisorption is not the rate determining step in the removal of $\mathrm{Mn}$ from solution by natural zeolite.

Models proposed by Weber and Morris and by Furusawa and Smith give the same conclusion. Boundary layer surrounding the particle is reduced and its effect is small, well intraparticular diffusion is more likely to be the rate determining step. According to the correlation coefficient $R^{2}$ it can be concluded that the intraparticle diffusion was not the only rate determining mechanism in the adsorption process, because $R^{2}$ is different at all initial Mn concentration and by increasing the concentration of $\mathrm{Mn}$ ions in solution, $R^{2}$ is also increasing. It means that at higher concentrations of $\mathrm{Mn}$ ions in solution, the film diffusion may take a part in the rate determining step. 


\section{REFERENCES}

[1] S. R. Taffarel, J. Rubio, On the removal of $\mathrm{Mn}^{2+}$ ions by adsorption onto natural and activated Chilean zeolites, Minerals Engineering, 22, 336-343 (2009).

[2] E. Erdem, N. Karapinar, R. Donat, The removal of heavy metal cations by natural zeolites, Journal of Colloid and Interface Science, Vol. 280, Issue 2, 309-314 (2004).

[3] G. D. Bogdanović, D. V. Antić, J. Begović, V. Stanković, Adsorption of heavy metals from aqueous solution by natural zeolite, Proceedings of the XIV Balkan Mineral Processing Congress, Tuzla, Bosnia and Herzegovina, 2011, pp. 773-778.

[4] G. D. Bogdanović, V. Stanković, D. V. Antić, S. Prodanović, L. Andrić, D. Vegner, Adsorption of copper and zink ions from acid mine drainage by natural zeolite, Proceedongs of the XV Balkan Mineral Processing Congress, Sozopol, Bulgaria, 2013, pp. 989-993.

[5] J. Perić, M. Trgo, N. Vukojević Medvidović, Removal of zinc, copper and lead by natural zeolite - A comparison of adsorption isotherms, Water Research, 38, 1893-1899 (2004)

[6] M. Minčeva, L. Markovska, V. Meško, Removal of $\mathrm{Zn}^{2+}, \mathrm{Cd}^{2+}$ and $\mathrm{Pb}^{2+}$ from binary aqueous solution by natural zeolite and granulated activated carbon, Macedonian Journal of Chemistry and Chemical Engineering, Vol. 26 (2), 125-134 (2007).

[7] M. Jovanović, N. Rajić, B. Obradović, Kinetic modeling of copper removal from aqueous solutions using natural zeolite, Proceedings of the 4th Slovenian-Croatian Symposium on Zeolites, pp. 81-84.

[8] B. Taenzana, Adsorption of cadmium, nickel and lead on modified natural zeolite, Master thesis, University of the Witwatersrand, Johannesburg, 2011.

[9] A. S. Sheta, A. M. Falatah, M. S. Al-Sewailem, E. M. Khaled, A. S. H. Sallam, Sorption characteristics of zinc and iron by natural zeolite and bentonite, Microporous and Mesoporous Materials, 61, 127-136 (2003).

[10] D. V. Dimitrovski, Z. Lj. Božinovski , K. T. Lisičkov, S. V. Kuvendjiev, Batch Adsorption of Nickel from Aqueous Solution by Natural Zeolite-Equilibrium Study, J. Chem. Chem. Eng., 5 , 528-534 (2011).

[11] T. Motsi, Remediation of acid mine drainage using natural zeolite, Doctotal thesis: School of Chemical Engineering, The University of Birmingham, U.K., 2010.
[12] K. A. Connors, Chemical Kinetics: The study of reaction rates in solution, VCH Publishers, USA, 1990.

[13] A. O. Okewale, K. A. Babayemi, A. P. Olalekan, Adsorption Isotherms and Kinetics Models of Starchy Adsorbents on Uptake of Water from Ethanol - Water Systems, International Journal of Applied Science and Technology, Vol. 3 (1), 35-42 (2013).

[14] Y. S. Ho, G. McKay, Pseudo-second order model for sorption processes, Process Biochemistry, 34, 451-465 (1999).

[15] T. Furusawa, J. M. Smith, Fluid-particle and intraparticle mass transport rates in slurries, Industrial and Engineering Chemistry Fundamentals, Vol. 12 (2), 197-203 (1973).

[16] Y. Sag, Y. Aktay, Mass transfer and equilibrium studies for the sorption of chromium ions onto chitin, Process Biochemistry, 36,157-173 (2000).

[17] G. Crini, P. Badot, Sorption processes and pollution: Conventional and non-conventional sorbents for pollutant removal from wastewater, Presses universitaires de France - Comte, 2010

[18] C. Sutherland, C. Venkobachar, A diffusion-chemisorption kinetic model for simulating biosorption using forest macro-fungus, fomes fasciatus, International Research Journal of Plant Science, Vol. 1(4), 107-117 (2010).

[19] R. M. Barrer, Zeolites and clay minerals as sorbents and molecular sieves, London, Academic Press Inc., 1978.

[20] C. E. Harland, Ion Exchange: Theory and Practice, second edition, The Royal Society of Chemistry, 1994.

[21] B. H. Hameed, M. I. El-Khaiary, Malachite green adsorption by rattan sawdust: Isotherm, kinetic, Journal of Hazardous Materials, 159, 574-579 (2008).

[22] I. A. W. Tan, B. H. Hameed, Adsorption isoterms, kinetics, thermodynamics and desorption studies of basic dye on activated carbon derived from oil palm empty fruit bunch, Journal of Applied Sciences, 25652571 (2010).

[23] A. Zendelska, M. Golomeova, K. Blažev, B. Krstev, B. Golomeov, A. Krstev, Sh. Jakupi, Equilibrium studies of manganese removal from aqueous solution by adsorption on natural zeolite, $V I^{\text {th }}$ International Metallurgical Congress, Ohrid, 2014.

[24] A. Findon, G. McKay, H. S. Blair, Transport studies for the sorption of copper ions by chitosan, Journal of Environmental Science and Health, Part A. Environmental Science and Engineering and Toxicology, Vol. 28 (1), 173-185, (1993). 